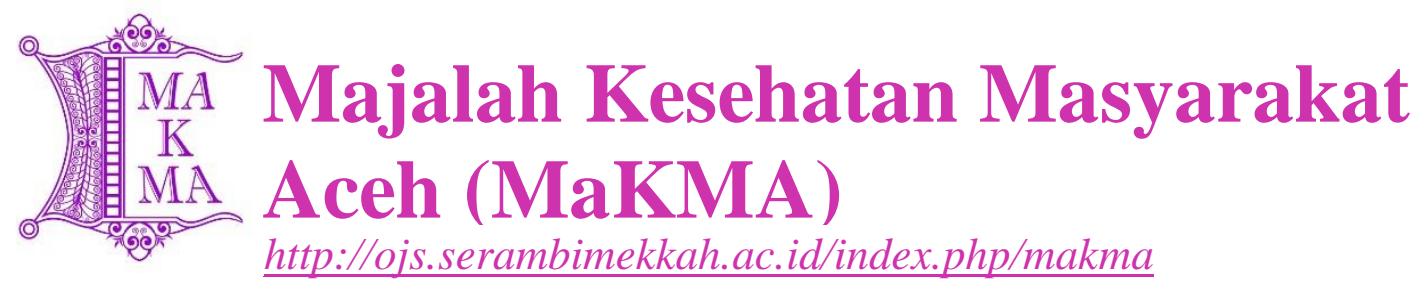

\title{
GAMBARAN DETERMINAN PERILAKU MASYARAKAT MEROKOK DALAM RUMAH DI WILAYAH KERJA PUSKESMAS $X$ BANYUWANGI
}

\author{
Nenda Puspita Sari ${ }^{\bowtie}$, Khofifatul Islamiyah, Jayanti Dian Eka Sari \\ Departemen Promosi Kesehatan dan Ilmu Perilaku, Program Studi Kesehatan Masyarakat PSDKU \\ Universitas Airlangga, Banyuwangi. \\ ${ }^{\bowtie}$ Alamat Korespondensi: JL. Pantai Waru Doyong RT.02/RW.03 Bulusan Krajan, Kalipuro, \\ Banyuwangi/nenda.puspita.sari-2015@fkm.unair.ac.id / 08113509397
}

\begin{abstract}
ABSTRAK
Salah satu indikator PHBS adalah perilaku merokok. Perilaku ini menjadi semakin berbahaya jika dilakukan di dalam rumah. Survei Mawas Diri yang dilakukan oleh Puskesmas X Banyuwangi menunjukkan hasil bahwa perilaku masyarakat merokok dalam rumah yaitu $43 \%$ atau $790 \mathrm{KK}$ dari 1840 KK yang disurvei. Tujuan dari penelitian ini untuk mengetahui determinan masyarakat berperilaku merokok dalam rumah. Penelitian ini merupakan penelitian deskripstif kuantitatif, menggunakan desain studi cross sectional. Data penelitian diambil dari Kartu Kesehata Keluarga (K3) dan Survei Mawas Diri (SMD). Sampel penelitian menggunakan total populasi yang diambil dari pengunjung unit rawat jalan Puskesmas X, yaitu 50 orang. Analisis data menggunakan google form untuk mengetahui distribusi masyarakat yang merokok dalam rumah. Hasil penelitian menunjukkan terdapat $70 \%$ masyarakat berperilaku merokok dalam rumah. $74 \%$ responden tahu tentang bahaya merokok dalam rumah. Stres menjadi alasan responden atau keluarga merokok yaitu 48,6\%. Sebesar $71,4 \%$ responden merokok saat santai. Beberapa responden ingin berhenti merokok, dengan cara bertahap $50 \%$, pengalihan makan atau minum $36,4 \%$ dan spontan $13,6 \%$. Kesimpulan dari penelitian ini adalah sebagian besar responden berperilaku merokok dalam rumah karena determinan perilaku internal dan eksternal. Berdasarkan hasil penelitian, maka guna meminimalisir jumlah perokok dalam rumah perlu dilakukan pemberian penyuluhan secara rutin dari pemegang program promosi kesehatan Puskesmas X, serta perlu adanya kerja sama dari keluarga, teman, dan pihak kesehatan untuk mendukung penerapan PHBS rumah tangga.
\end{abstract}

Kata Kunci: Perilaku, Merokok, PHBS, Promosi Kesehatan, Puskesmas, Rumah 


\title{
DESCRIPTION OF DETERMINANTS OF HOUSEHOLD SMOKING COMMUNITIES IN THE WORKING AREA OF PUSKESMAS X BANYUWANGI
}

\begin{abstract}
One indicator of PHBS is smoking behavior. This behavior becomes increasingly dangerous if done in the house. The Self-Monitoring Survey conducted by Puskesmas X Banyuwangi showed that the behavior of the smoking community in the home was $43 \%$ or 790 households from 1840 households surveyed. The purpose of this study is to determine the determinants of smoking behavior in the home. This research is a descriptive quantitative research, using a cross sectional study design.The research data was taken from the Family Health Card (K3) and the Self-Observation Survey (SMD). The study sample used the total population taken from visitors to the outpatient unit of Puskesmas X, which was 50 people. Data analysis using google form to determine the distribution of people who smoke in the home. The results of the study showed that $70 \%$ of the people were smoking in their homes. $74 \%$ of respondents knew about the dangers of smoking in the home. Stress is the reason for respondents or families to smoke, which is $48.6 \%$. As many as $71.4 \%$ of respondents smoke when relaxed. Some respondents want to stop smoking, by gradually 50\%, diverting food or drink $36.4 \%$ and spontaneously $13.6 \%$. The conclusion of this study is that most of the respondents smoke in the house because of the determinants of internal and external behavior. Based on the results of the study, in order to minimize the number of smokers in the home it is necessary to provide routine counseling from the health center health promotion program holder $\mathrm{X}$, and the need for cooperation from family, friends, and health parties to support the implementation of household CHL.
\end{abstract}

Keywords: Behaviour, Clean and Healthy Lifestyle (CHL), House, Health Center, Health Promotion, Smoke 


\section{PENDAHULUAN}

Perilaku Hidup Bersih dan Sehat atau yang biasa disingkat dengan PHBS adalah perilaku kesehatan yang dilakukan atas kesadaran diri sendiri sehingga anggota keluarga dapat menolong dirinya sendiri di bidang kesehatan dan berperan aktif dalam berbagai kegiatan kesehatan di masyarakat. PHBS juga diartikan sebagai tindakan atas dasar kesadaran dari hasil pembelajaran yang menjadikan seorang anggota keluarga dapat menolong dirinya sendiri di bidang kesehatan dan berperan aktif dalam mewujudkan kesehatan masyarakat ${ }^{1}$. Salah satu upaya penting yang dapat dilakukan yaitu melalui pendekatan rumah tangga, sekolah atau institusi pendidikan, tempat kerja, institusi kesehatan dan tempat umum ${ }^{1}$.

PHBS pada tatanan rumah tangga dapat dilakukan melalui pemberdayaan keluarga atau anggota rumah tangga. Komunikasi dan interaksi yang terjalin antar anggota keluarga menjadi awal penting dalam terbentuknya perilaku berwawasan kesehatan. Pelaksanaan PHBS tingkat rumah tangga terdiri dari persalinan ditolong oleh tenaga kesehatan, memberi bayi ASI ekslusif, menimbang balita setiap bulan, menggunakan air bersih, mencuci tangan dengan air bersih yang mengalir dan menggunakan sabun, menggunakan jamban yang sehat, memberantas jentik di rumah sekali seminggu, makan sayur dan buah setiap hari, melakukan aktivitas fisik setiap hari dan tidak merokok di dalam rumah $^{1}$.

Hasil Survei Mawas Diri (SMD) di wilayah kerja Puskesmas $\mathrm{X}$ menunjukkan 3 PHBS yang masih belum mencapai target, diantaranya adalah rendahnya ASI ekslusif yaitu $69 \%$ atau 109 KK dari $1840 \mathrm{KK}$ yang disurvei, rendahnya perilaku tidak merokok dalam rumah yaitu $43 \%$ atau $790 \mathrm{KK}$ dari $1840 \mathrm{KK}$ yang disurvei, kemudian rendahnya perilaku BAB di jamban yaitu $61 \%$ atau $1115 \mathrm{KK}$ dari $1840 \mathrm{KK}$ yang disurvei [Tabel 1]. Hasil ini menunjukkan bahwa masih rendahnya cakupan penerapan PHBS di tingkat rumah tangga. Salah satu masalah yang sampai saat ini sulit untuk diselesaikan yaitu kesadaran perokok aktif untuk tidak merokok di dalam rumah. Beberapa penelitian sudah menjelaskan bahwa perokok pasif memiliki risiko terjangkit penyakit akibat rokok lebih besar daripada perokok aktif. Asap yang berada di dalam rumah sangat berbahaya terutama jika dihirup setiap harinya oleh kelompok rentan, seperti anak-anak dan lansia.

Masalah kesehatan tersebut
tentunya menjadi tugas besar Puskesmas X di wilayah kerja setempat untuk meningkatkan kesadaran bahaya perilaku merokok terutama di dalam rumah. Hal tersebut sesuai dengan Keputusan Menteri Kesehatan nomor 585 tahun 2007 tentang Pedoman Pelaksanaan Promosi Kesehatan di Puskesmas. Promosi kesehatan di Puskesmas merupakan upaya puskesmas melaksanakan pemberdayaan kepada masyarakat untuk mencegah penyakit dan meningkatkan kesehatan setiap individu, keluarga serta lingkungan secara mandiri dan mengembangkan upaya kesehatan bersumber masyarakat. Secara operasional, upaya promosi kesehatan puskesmas dilakukan agar masyarakat mampu berperilaku hidup bersih dan sehat sebagai bentuk pemecahan berbagai masalah kesehatan yang dihadapi, baik yang sedang diderita ataupun yang mampu berpotensi mengancam kesehatan ${ }^{2}$.

Puskesmas $\mathrm{X}$ yang memiliki peran besar dalam angka kasus di 
wilayah $\mathrm{X}$ telah memiliki beberapa kegiatan untuk menangani hal tersebut, seperti penyuluhan di posyandu, institusi pendidikan, tempat kerja dan tempat-tempat umum serta membuat KTR di lingkungan kerja Puskesmas X. Program yang memiliki tanggung jawab besar dalam masalah rokok ini adalah program Promosi Kesehatan, lintas program dengan Kesehatan

\section{METODE}

Penelitian ini merupakan penelitian deskripstif kuantitatif dengan menggunakan desain studi cross sectional. Penelitian ini dilakukan di UPTD Puskesmas X, Kecamatan X, Kabupaten Banyuwangi. Waktu pengumpulan data adalah awal bulan Maret 2019. Data pendukung yang digunakan berasal dari data sekunder puskemas yaitu survey K3 (Kartu Kesehatan Keluarga) dan SMD (Survei Mawas Diri) yang dilakukan pada 20\% penduduk Kecamatan $\mathrm{X}$ untuk mengetahui presentase dari masingmasing indikator PHBS. Pengambilan data dilakukan selama 2 hari di unit rawat jalan Puskesmas $\mathrm{X}$. Jumlah populasi yang diambil adalah seluruh pasien yang melakukan pemeriksaan atau kunjungan di unit tersebut selama pengambilan data yaitu sejumlah 50 orang. Sampel pada penelitian ini menggunakan total populasi dari

\section{HASIL}

Berdasarkan hasil dari penelitian menunjukkan terdapat $70 \%$ yang merokok atau memiliki keluarga sebagai perokok aktif di dalam rumah. Berdasarkan hasil penelitian menunjukkan bahwa pada usia 15-17 tahun sudah terpengaruh oleh perilaku merokok. $16 \%$ responden menjawab mulai merokok pada usia kurang dari 15 tahun, 22\% merokok sejak umur 15-17
Lingkungan. Program Promosi Kesehatan Puskesmas X telah memiliki Plan of Action (POA) setiap tahunnya untuk meningkatkan capaian. Namun, karena keadaan di lapangan tidak semudah yang di rencanakan maka perlu adanya beberapa inovasi atau cara lain yang menyentuh ke masyarakat.

seluruh pasien yang melakukan pemeriksaan atau kunjungan di unit rawat jalan Puskesmas X.

Pengumpulan data penelitian ini dilakukan dengan cara membagikan kuesioner pada responden saat pasien atau keluarga pasien menunggu nomor antrian di ruang tunggu Puskesmas $\mathrm{X}$ dan melakukan wawancara kepada responden. Setiap pasien atau keluarga pasien mendapatkan kuesioner dan arahan dalam mengisi kuesioner. Kuesioner berisi 10 indikator PHBS di tingkat rumah tangga. Penelitian ini nantinya dapat menjawab berapa banyak masyarakat yang merokok, tingkat pengetahuan bahaya merokok, alasan merokok, sejak kapan, keinginan berhenti merokok, serta cara apa yang dapat meningkatkan kesadaran masyarakat terkait bahaya merokok dalam rumah. Analisa data penelitian ini menggunakan google form untuk melihat distribusi presentase setiap variabel yang diteliti.

tahun, dan $12 \%$ pada umur 17 tahun keatas [Gambar 1]. Pengetahuan perilaku merokok dalam rumah yang mereka dan keluarga mereka lakukan sebesar $74 \%$ mengetahui bahaya dari rokok.

Selain itu, masyarakat atau keluarga yang merokok memiliki alasan merokok paling banyak dikarenakan menurut mereka dapat membuat pikiran tenang setelah merokok memiliki 
presentase $48,6 \%$. Sedangkan alasan lain yaitu karena mengikuti orang tua sebanyak $22,9 \%$, diajak teman sebaya $20 \%$, dan ingin terlihat gaya yaitu $8,6 \%$. Pada [Gambar 2] menunjukkan hasil keadaan atau saat seperti apa yang membuat orang merokok. Hasil penelitian menunjukkan kebanyakan masyarakat merokok adalah ketika santai yaitu 71,4\% dan disusul dengan keadaan saat bosan dan saat melihat orang lain merokok yaitu $34,3 \%$. Masyarakat yang sudah kecanduan

\section{PEMBAHASAN}

Merokok menjadi kebiasaan buruk yang merajarela di kalangan masyarakat luas. Dampak yang dihasilkan oleh rokok tidak dirasakan oleh sebagian orang sebagai dampak yang membahayakan kesehatan. Banyak orang tidak peduli dan acuh dengan dampak tersebut. Bahkan, banyak diantaranya yang memiliki perilaku buruk, seperti merokok yang dilakukan di dalam rumah. Kumpulan asap rokok yang dihasilkan oleh rokok tersebut mengendap di udara dan terhirup secara terus menerus oleh anggota keluarga. Tentunya, hal ini sangat berbahaya terutama bagi kelompok rentan sebagai perokok pasif, seperti anak-anak dan lansia. Keluarga yang memiliki perokok aktif dalam rumah tergolong sebagai keluarga tidak sehat.

Berdasarkan Riskesdas (2018), prevalensi konsumsi tembakau (hisap dan kunyah) pada usia usia $\geq 15$ tahun masih fluktuatif karena cenderung meningkat pada 2007 ke 2013 dari $34,2 \%$ menjadi $36,3 \%$, pada 2016 turun menjadi $32,8 \%$ dan meningkat kembali pada 2018 yaitu $33,8 \%{ }^{4}$.

Demi menekan kebiasaan merokok dibutuhkan upaya dari berbagai pihak dalam menanganinya. Salah satu pihak yang berperan dalam hal tersebut adalah puskesmas pada merokok memiliki keinginan sebanyak $62,9 \%$ untuk berhenti merokok. Menurut responden cara terbaik untuk bisa berhenti merokok adalah bertahap sebesar 50\%, pengalihan seperti makan, bekerja, dan lain-lain yaitu 36,4\% dan spontan sebesar 13,6\%. Masyarakat wilayah kerja Puskesmas X memberikan pilihan lebih banyak untuk pemberian informasi terkait bahaya rokok melalui penyuluhan yaitu $60,4 \%$

[Gambar 3].

bagian promosi kesehatan. Puskesmas sebagai pelayanan kesehatan bertanggung jawab dalam menjaga kesehatan masyarakat di wilayah kerjanya. Kegiatan promosi kesehatan perlu digencarkan semaksimal mungkin, salah satunya dengan PHBS. Hasil penelitian menunjukkan kegiatan promosi kesehatan yang dilakukan oleh puskesmas X sudah cukup baik dan sesuai dengan Keputusan Menteri Kesehatan nomor 1114/Menkes/SK/VII/2005 tentang Pedoman Pelaksanaan Promosi Kesehatan di Daerah ${ }^{5}$.

Kebiasaan merokok yang terjadi di masyarakat tidak luput dari berbagai faktor yang mempengaruhinya, baik dari faktor internal maupun eksternal. Faktor internal meliputi tingkat kesadaran masyarakat terhadap rokok yang tergolong rendah. Mereka belum mengenal betul dampak panjang dari tidak ber-PHBS. Sedangkan, faktor eksternal meliputi lingkungan sekitar sepeti keluarga dan teman sebaya. Berdasarkan penelitian lain, menyebutkan bahwa ada hubungan pengaruh keluarga dengan perilaku merokok pada remaja di SMP 1 Slogohimo Kabupaten Wonogiri. Responden dengan pengaruh keluarga yang kuat dengan perilaku merokok 
positif sebanyak $25(35,2 \%)$ dari 35 $(49,3 \%)^{11}$.

Hasil penelitian menunjukkan bahwa kondisi PHBS tatanan rumah tangga masyarakat di wilayah puskesmas $\mathrm{X}$ memiliki rata-rata angka tidak merokok yang rendah, artinya masih banyak masyarakat yang merokok dalam rumah. Usia terpengaruhnya merokok pada masyarakat kebanyakan pada usia remaja yaitu 15-17 tahun. Usia tersebut merupakan rentang usia manusia mulai tumbuh remaja, yang memiliki rasa ingin tahu dan coba-coba. Faktor terbanyak yang mempengaruhi terjadinya kebiasaan merokok adalah sugesti bahwa rokok adalah salah satu cara untuk membuat pikiran tenang saat sedang memiliki masalah. Sedangkan, faktor tertinggi kedua yaitu mengikuti kebiasaan orang tua. Berdasarkan penelitian lain, faktor psikososial yang berhubungan dengan perilaku merokok di usia remaja antara lain stress dan proses coping pada keluarga. Lingkungan sosial memiliki pengaruh dalam pembentukan sikap, keyakinan, dan intesitas dalam merokok. Orang tua merupakan cotoh dan model bagi remaja di dalam rumah, tetapi bagi orang tua yang kurang paham tentang kesehatan secara tidak langsung mereka memberikan contoh perilaku atau pola hidup kurang sehat ${ }^{7}$.

Hasil penelitian menyebutkan bahwa paling banyak orang merokok dimana saja, artinya merokok di dalam rumah juga sudah termasuk di dalamnya. Selain itu, hal tersebut juga diartikan bahwa perilaku merokok tidak peduli dengan batasan tempat dan lingkungan. Hal ini sejalan dengan penelitian lain yaitu, menunjukkan bahwa 199 responden penelitian yang berada di Kelurahan Tarok, Kecamatan Payakumbuh Utara, sebagian besar responden memiliki perilaku merokok di dalam rumah sebanyak 145 responden $(89,5 \%)$, lebih dari separuh responden bersikap negatif pada perilaku merokok sebanyak 101 responden $(62,3 \%)$, lebih dari separuh responden memiliki perceived behavioral yang tinggi sebanyak $(51,2 \%)$. Perilaku merokok dalam rumah dapat berdampak terhadap munculnya perokok pasif di dalam rumah. Banyak faktor yang mempengaruhi dan mendorong masyarakat merokok terutama merokok di dalam rumah, baik dari dalam masing-masing individu maupun dari luar individu tersebut ${ }^{10}$.

Berdasarkan hasil penelitian ini, masyarakat merokok disaat santai bersama keluarga. Hasil tersebut sesuai dengan penelitian yang dilakukan oleh ${ }^{9}$, yaitu faktor-faktor yang mendukung kepala keluarga untuk merokok di dalam rumah antara lain ketika sedang santai atau sedang tidak ada pekerjaan di rumah, ketika menonton televisi, ketika berkumpul bersama keluarga di rumah (anak/istri/orang tua/mertua), serta setelah makan dan saat minum kopi. Semakin mudah individu untuk merokok, maka intensi atau niat untuk merokok nya juga semakin tinggi.

Puskesmas $\mathrm{X}$ dalam menjalankan promosi kesehatan terkait larangan merokok di dalam rumah dilakukan secara terus menerus kepada masyarakat. Promosi diberikan pada kegiatan posyandu, UKS, prolanis, dan lain-lain. Kegiatan lain yang dilaksanakan oleh program promosi kesehatan adalah dilakukan pemicuan kepada masyarakat melalui rangsangan agar dapat menular ke masyarakat. Hal ini juga dijelaskan oleh penelitian lain yaitu promosi dan edukasi diberikan pada masyarakat secara langsung dengan menyampaikan materi pada saat rakordis dan posyandu. Selain itu, kegiatan juga dapat dilakukan pada 
anak-anak sekolah sebagai bahan pembekalan di sekolah. Edukasi tentang bahaya rokok pada anak sekolah penting untuk dilakukan sebagai upaya pencegahan karena usia sekolah rentan untuk memulai merokok ${ }^{10}$. Selain itu,

\section{KESIMPULAN DAN SARAN}

Merokok dalam rumah merupakan perilaku yang tidak sesuai dengan kaidah kesehatan dan menimbulkan dampak buruk bagi kesehatan terutama bagi anggota keluarga sebagai perokok pasif. Kebiasaan merokok muncul akibat faktor internal dan eksternal. Persepsi bahwa merokok dapat memunculkan rasa tenang dalam diri masyarakat menjadi alasan utama dalam merokok. Salah satu hal yang perlu dilakukan yaitu menggencarkan terkait dengan PHBS demi menciptakan lingkungan yang sehat. Tenaga kesehatan, terutama bidang promosi kesehatan, menerapkan program penyuluhan secara rutin dan merata keseluruh wilayah Puskesmas X. Penyuluhan dibuat semenarik mungkin melalui aksi sosial serta berbagai media elektronik, seperti gambar, video berdasarkan hasil penelitian lain menjelaskan bahwa upaya pencegahan merokok pada anak sekolah harus menjadi perhatian penting bagi petugas kesehatan dan jajaran dinas kesehatan ${ }^{10}$.

edukasi, dan lain-lain. Selain itu, supaya timbul rasa motivasi merubah perilaku tersebut maka perlu adanya bentuk apresiasi dari Puskesmas $\mathrm{X}$ untuk keluarga yang sudah mampu menerapkan tidak merokok dalam rumah. Selain saran untuk pihak tenaga kesehatan, perlu juga bagi masyarakat untuk meningkatkan rasa peduli dalam diri sendiri dengan cara peningkatan pengetahuan masyarakat secara terus menerus yang diyakini mampu menekan kebiasaan merokok secara signifikan. Kerja sama dari keluarga, teman, dan pihak kesehatan sangat diperlukan untuk mendukung penerapan PHBS dalam tatanan rumah tangga. Secara bertahap cara ini diharapkan mampu untuk mengubah kebiasaan merokok pada masyarakat luas. 
DAFTAR PUSTAKA

1. Departemen Kesehatan RI: (2009).

2. Keputusan Menteri Kesehatan Republik Indonesia Nomor 585 Tahun 2007 Tentang Pedoman Pelaksanaan Promosi Kesehatan di Puskesmas, Jakarta : (2007)

3. Profil Puskesmas X tahun (2018)

4. Riset Kesehatan Dasar. 2018, Hasil Utama Riskesdas 2018. Badan Penelitian dan Pengembangan Kesehatan. Jakarta: Kementerian Kesehatan RI.

5. Keputusan Menteri Kesehatan nomor 1114/Menkes/SK/VII/2005 tentang Pedoman Pelaksanaan Promosi Kesehatan di Daerah, Jakarta (2005)

6. Peraturan Menteri Kesehatan Republik Indonesia No. 2269 Tahun 2011 Tentang Pedoman Pembinaan Perilaku Hidup Bersih dan Sehat (PHBS), Jakarta: (2011)

7. Susanto, D.N. Hubungan antara dukungan negatif orang tua dengan perilaku merokok pada remaja di desa Puro kecamatan Karangmalang kabupaten Sragen. [Skripsi]. Fakultas Ilmu Kesehatan UMS, Surakarta: (2013).
8. Peraturan Menteri Kesehatan Republik Indonesia Nomor 75 Tahun 2014 Tentang Pusat Kesehatan Masyarakat, Jakarta: (2014)

9. Haryani. Hubungan Sikap, Norma Subjektif dan Perceived Behavioral Control dengan Intensi Kepala Keluarga yang Untuk Merokok di Dalam Rumah di Kelurahan Majasari Tahun 2014. Jurnal Ilmu Kesehatan Masyarakat. (2015);6 (0): 41-46.

10. Ediana, D. Faktor-Faktor yang Berhubungan dengan Perilaku Merokok di Dalam Rumah di Kelurahan Tarok. Jurnal Human Care. (2016); (1): 2528-66510.

11. Kustanti, dkk.Hubungan Antara Pengaruh Keluarga, Pengaruh Teman dan Pengaruh Iklan Terhadap Perilaku Merokok Pada Remaja di SMPN 1 Slogohimo, Wonogiri [Skripsi]. Publikasi Ilmiah FIK Universitas Muhammadiyah Surakarta, Surakarta: (2016). 


\section{LAMPIRAN}

[Tabel 1]. Kondisi Perilaku Hidup Bersih dan Sehat (PHBS) Masyarakat

\begin{tabular}{llcccccc}
\hline No & Desa & $\begin{array}{c}\text { Air } \\
\text { bersih }\end{array}$ & $\begin{array}{c}\text { Jamban } \\
\text { sehat }\end{array}$ & $\begin{array}{c}\text { Cuci } \\
\text { Tangan }\end{array}$ & PSN & $\begin{array}{c}\text { Tidak } \\
\text { Merokok }\end{array}$ & $\begin{array}{c}\text { Rumah } \\
\text { Tangga Sehat }\end{array}$ \\
\hline $\mathbf{1}$ & A (188kk) & $100 \%$ & $55,85 \%$ & $100 \%$ & $80,31 \%$ & $70,74 \%$ & $41,48 \%$ \\
$\mathbf{2}$ & B (290kk) & $100 \%$ & $70 \%$ & $93,10 \%$ & $92,75 \%$ & $28,27 \%$ & $25,51 \%$ \\
$\mathbf{3}$ & C (214kk) & $100 \%$ & $51,40 \%$ & $100 \%$ & $100 \%$ & $45,79 \%$ & $36,44 \%$ \\
$\mathbf{4}$ & D (232kk) & $100 \%$ & $45,25 \%$ & $100 \%$ & $100 \%$ & $35,34 \%$ & $29,74 \%$ \\
$\mathbf{5}$ & E (235kk) & $100 \%$ & $76,59 \%$ & $100 \%$ & $97,44 \%$ & $35,74 \%$ & $30,63 \%$ \\
$\mathbf{6}$ & F (235kk) & $100 \%$ & $62.97 \%$ & $100 \%$ & $99,57 \%$ & $48,08 \%$ & $28,93 \%$ \\
$\mathbf{7}$ & G (235kk) & $100 \%$ & $67,65 \%$ & $100 \%$ & $100 \%$ & $61,27 \%$ & $46,80 \%$ \\
$\mathbf{8}$ & H (235kk) & $99 \%$ & $67,23 \%$ & $95,74 \%$ & $94,46 \%$ & $30,63 \%$ & $25,53 \%$ \\
\hline
\end{tabular}

Sumber: Profil Puskesmas X Banyuwangi, 2018

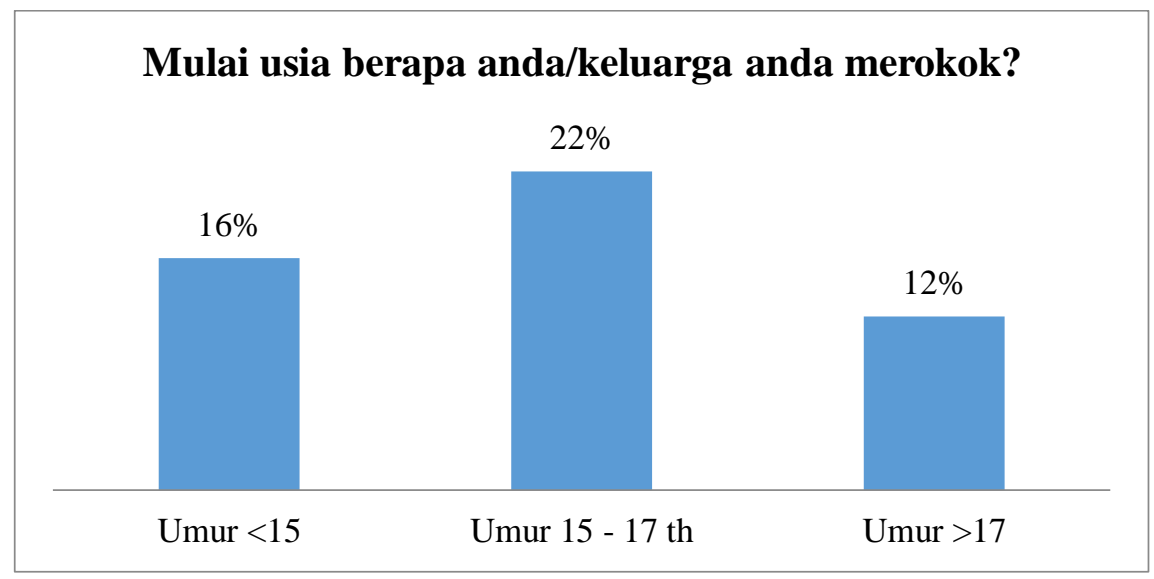

[Gambar 1]. Hasil Usia Responden atau Keluarga Mulai Merokok

\section{Keadaan apa yang membuat anda/keluarga merokok?}

35 responses

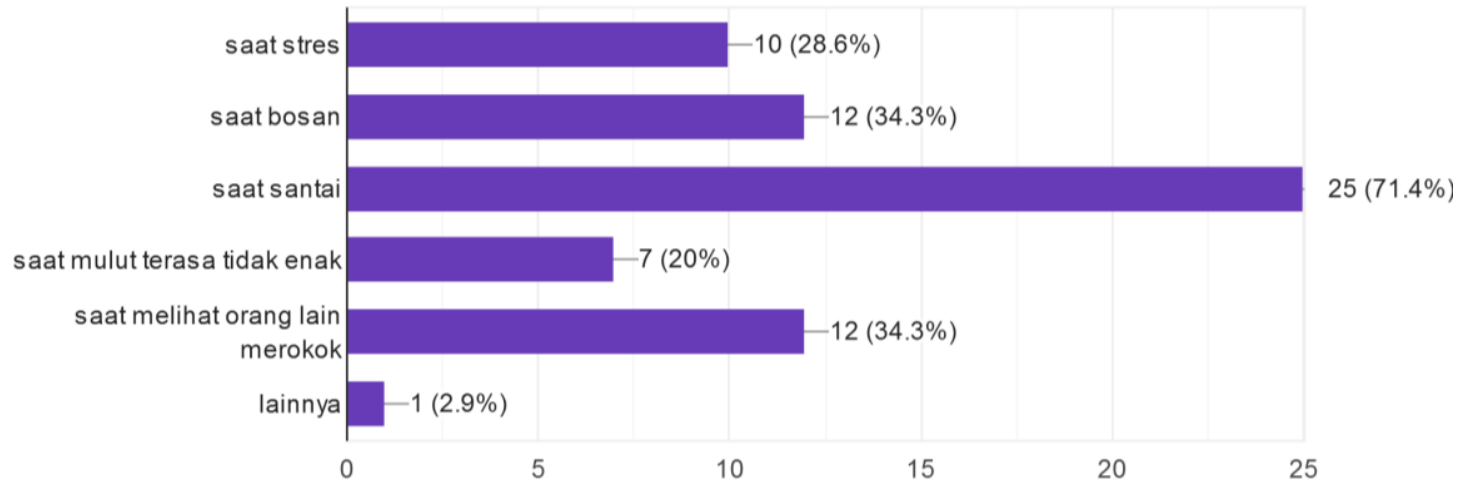

[Gambar 2] Hasil Keadaan yang Membuat Responden atau Keluarga Merokok 
Menurut anda, bagaimana cara pemberian informasi yang tepat ttg bahaya merokok yg dapat berpengaruh sehing...yang merokok bisa berhenti merokok? 48 responses

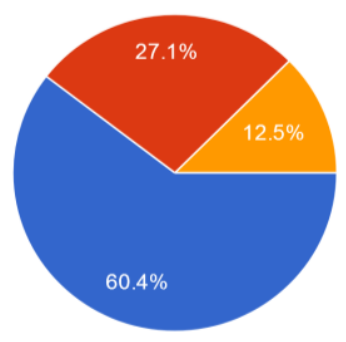

penyuluhan

lainnya

[Gambar 3] Hasil Cara Pemberian Informasi Menangani Kebiasaan Merokok yang Diinginkan Masyarakat 